\title{
Focus on gastrointestinal system in critically ill patients
}

\author{
Emmanuel Weiss ${ }^{1,2,3^{*}}$ (1) and Yaseen M. Arabi ${ }^{4,5,6}$ (])
}

๑ 2020 Springer-Verlag GmbH Germany, part of Springer Nature

Gastrointestinal or intra-abdominal conditions are a major cause for critical illness. Additionally, critical illness precipitates gastrointestinal injury, mediated by hypoperfusion, hypoxia and systemic inflammation. This editorial reviews the progress made on gastrointestinal issues in critically ill patients as reported in the recent literature in order to focus on the needs for further research in this field (Fig. 1).

A recent observational study by the Abdominal Sepsis Study (AbSeS) group (from European Society of Intensive Care Medicine) included 2621 patients with intraabdominal infection from 42 countries and reported a mortality rate of $29.1 \%$ [1]. The prevalence of antimicrobial resistance was $26.3 \%$; worryingly, it was equally common in community-acquired as in hospital-acquired infection [1].

Beside intra-abdominal infections, one of the important manifestations of gastrointestinal injury during critical illness is stress-related gastrointestinal bleeding (GIB), which is associated with an increased risk of death and length of stay in the intensive care unit (ICU) [2]. Nevertheless, the routine prescription of stress ulcer prophylaxis has been debated. Because new relevant trials including the SUP-ICU trial [3] were recently published, Barbateskovic et al. [4] conducted a systematic review with meta-analysis of randomized clinical trials assessing the effects of proton pump inhibitor (PPI) or histamine-2-receptor antagonists (H2RA) versus placebo or no prophylaxis on mortality, GIB and adverse events. Analyzing 42 trials that included 6899 ICU patients, they

\footnotetext{
*Correspondence: emmanuel.weiss@aphp.fr

1 Department of Anesthesiology and Critical Care, Beaujon Hospital, DMU Parabol, AP-HP.Nord, Paris, 100 bld du general Leclerc, 92110 Clichy, France

Full author information is available at the end of the article
}

found that PPI or H2RA did not improve mortality but reduced GIB by almost 50\%. However, the effects on clinically important GIB, serious adverse events, healthrelated quality of life, myocardial ischemia, pneumonia and $C$. difficile enteritis remained inconclusive.

In order to identify patients at highest risk of GIB, Granholm et al. [5] performed a systematic review and meta-analysis assessing potential predictors of clinically important GIB and overt GIB in adult ICU patients. While confirming the low incidences of clinically important GIB and overt GIB (ranging from 0.6 to $2.8 \%$ and 1.3 to $12.8 \%$, respectively), they found that acute kidney injury (AKI), coagulopathy, shock and chronic liver disease were consistently associated with increased risk of GIB. In a specific meta-analysis, Butler et al. [6] reported that systemic corticosteroids might also increase the risk of clinically important GIB slightly, although this effect was unclear given the rarity of bleeding events, infrequent trial reporting and high risk of bias that reduced the overall quality of evidence.

Conversely, there are data suggesting a protective role of enteral nutrition against gastrointestinal tract injury in critically ill patients [5]. Enteral nutrition may, on the one hand, have beneficial effect by limiting bowel villous atrophy. On the other hand, it may have deleterious effects by compromising gut perfusion, especially in case of shock. In an ancillary study of the NUTRIREA-2 trial [7], Piton et al. [8] further investigated this question by comparing the effect of early full enteral nutrition versus early full parenteral nutrition on the bowel mucosa of ventilated adults with shock, using intestinal biomarkers. Early full enteral nutrition compared to early full parenteral nutrition was associated with increased plasma citrulline concentration, a marker for enterocyte mass, suggesting better restoration of enterocyte mass and mucosal trophicity. At the same time, early full enteral nutrition was associated

\section{Springer}


Potential research needs in the field of gastrointestinal system in critically ill patients

Field of research

Potential research needs

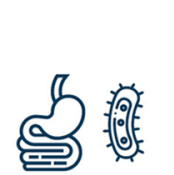

Intra-abdominal infections

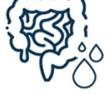

Stress-induced gastrointestinal bleeding

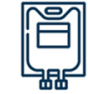

Nutrition

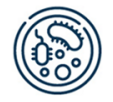

Microbiota
Definitions and classification of intra-abdominal infections (including

intra-abdominal candidiasis) need to be homogenized and standardized

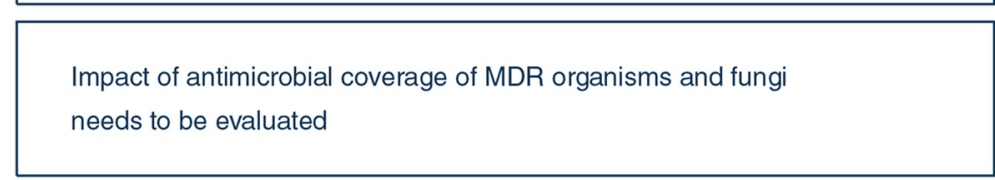

Analyse the effect of stress ulcer prophylaxis in specific subpopulations

such as patients at high risk for GI bleeding and severely-ill patients

Investigate the effect of stress ulcer prophylaxis on long term outcomes

and health-related quality of life, and conduct a cost-effective analysis

to anabolic phase of critical illness to tailor nutrition delivery

Study how to optimize enteral nutrition in order to have only beneficial

effects on villi without deleterious effects of small bowel ischemia

Investigate whether the nutritional strategy should differ in certain type

of patients (undernourished, acute kidney injury)

Improve knowledge on micronutrient pathophysiology and requirements

during critical illness

Identify the target population, optimal timing, mode of administration

and the ultimate effect on patients' outcome of fecal microbiota

transplantation in the ICU setting

Fig. 1 Potential research needs in the field of gastrointestinal system in critically ill patients

with higher plasma concentrations of the intestinal fatty acid binding protein (I-FABP), a marker of enterocyte damage, raising the question about potential subclinical ischemic injury to the mucosa [9]. These results support the current paradigm of early initiation of enteral nutrition to minimize harm from full starvation, but at the same time advancing enteral nutrition over the first few days of critical illness, reaching full 
amounts of energy with the transition into anabolic recovery phase [10]. The amount of micronutrients to deliver during critical illness is still debated; the results of a recent randomized controlled trial showed no benefit of early vitamin D3 supplementation in high-risk patients [11], but the results of several ongoing RCTs should be followed to know whether the provision of dietary reference intakes is sufficient or additional repletion should be considered during critical illness [12]. Furthermore, whether the above principles should apply across all patient types remains to be determined. For instance, high-quality data related to nutrition in patients with AKI in whom baseline deficiency of calories, proteins, vitamins and trace elements may be worsen by renal replacement therapy are lacking [13].

Enteral feeding intolerance (EFI), another manifestation of gastrointestinal injury, is often managed by prokinetics with limited efficacy. The PROMOTE trial compared the novel prokinetic ulimorelin (ghrelin agonist) to metoclopramide for 5 days in 120 critically ill patients with EFI [14]. The efficacy of the two drugs in the treatment of EFI was not different. Notably, only 51 and $55 \%$ of patients (ulimorelin and metoclopramide, respectively) achieved feeding success over the 5 treatment days despite using a volume-based protocol together with prokinetics. Given the transient nature of EFI, and the potential side effects of prokinetics, their optimal indications remain to be determined [15].

Gut microbiota changes are recognized to be associated with profound state of immunosuppression and an increased risk of bacterial infections, organ failure and death. Mitigating this dysbiosis may represent a promising approach to improve ICU patient outcome [16]. Fecal microbiota transplantation (FMT) has been shown to be effective for the treatment of severe $C$. difficile infections, paving the way for further evaluation in ICU patients. However, FMT remains understudied in this setting and several practical considerations regarding patient selection, donor screening, route of administration remain to be addressed before the use of FMT in the ICU. FMT safety should also be examined: recent data show a significant risk of bacteraemia associated with the use of probiotic Lactobacilli in the ICU and identify cases of transmission of probiotics from capsule to blood in ICU patients [17].

The studies reviewed in this paper further confirm the central role of the GI system in the pathogenesis of critical illness and highlight the evolving knowledge regarding the effects of therapeutic interventions of the GI system on the outcome of critically ill patients. Research on gastrointestinal issues in critically ill patients should continue (Fig. 1).

\begin{abstract}
Author details
${ }^{1}$ Department of Anesthesiology and Critical Care, Beaujon Hospital, DMU Parabol, AP-HP.Nord, Paris, 100 bld du general Leclerc, 92110 Clichy, France. ${ }^{2}$ Inserm UMR_S1 149, Inserm et Université de Paris, Paris, France. ${ }^{3}$ EASL CLIF Consortium, European Foundation for the Study of Chronic Liver Failure; EF CLIF, Barcelona, Spain. ${ }^{4}$ Intensive Care Department, Ministry of National Guard Health Affairs, Riyadh, Kingdom of Saudi Arabia. ${ }^{5}$ King Abdullah International Medical Research Center, Riyadh, Kingdom of Saudi Arabia. ${ }^{6}$ King Saud Bin Abdulaziz University for Health Sciences, Riyadh, Kingdom of Saudi Arabia.
\end{abstract}

\section{Compliance with ethical standards}

\section{Conflict of interest}

EWeiss reports personal fees from Baxter, MSD France, Biomerieux and Akcea therapeutics and travel reimbursements from MSD France. Y. M. Arabi has no conflict of interest to declare.

\section{Publisher's Note}

Springer Nature remains neutral with regard to jurisdictional claims in published maps and institutional affiliations.

Received: 4 February 2020 Accepted: 19 May 2020

Published online: 8 June 2020

\section{References}

1. Blot S, Antonelli M, Arvaniti K, Blot K, Creagh-Brown B, de Lange D, De Waele J, Deschepper M, Dikmen Y, Dimopoulos G, Eckmann C, Francois G, Girardis M, Koulenti D, Labeau S, Lipman J, Lipovestky F, Maseda E, Montravers P, Mikstacki A, Paiva JA, Pereyra C, Rello J, Timsit JF, Vogelaers D, Abdominal Sepsis Study group on behalf of the Trials Group of the European Society of Intensive Care M (2019) Epidemiology of intra-abdominal infection and sepsis in critically ill patients: "AbSeS", a multinational observational cohort study and ESICM Trials Group Project. Intensive Care Med 45:1703-1717

2. Krag M, Perner A, Wetterslev J, Wise MP, Borthwick M, Bendel S, McArthur C, Cook D, Nielsen N, Pelosi P, Keus F, Guttormsen AB, Moller AD, Moller $\mathrm{MH}$ et al (2015) Prevalence and outcome of gastrointestinal bleeding and use of acid suppressants in acutely ill adult intensive care patients. Intensive Care Med 41:833-845

3. Krag M, Marker S, Perner A, Wetterslev J, Wise MP, Schefold JC, Keus F, Guttormsen AB, Bendel S, Borthwick M, Lange T, Rasmussen BS, Siegemund M, Bundgaard H, Elkmann T, Jensen JV, Nielsen RD, Liboriussen L, Bestle MH, Elkjaer JM, Palmqvist DF, Backlund M, Laake JH, Badstolokken PM, Gronlund J, Breum O, Walli A, Winding R, Iversen S, Jarnvig IL, White JO, Brand B, Madsen MB, Quist L, Thornberg KJ, Moller A, Wiis J, Granholm A, Anthon CT, Meyhoff TS, Hjortrup PB, Aagaard SR, Andreasen JB, Sorensen CA, Haure P, Hauge J, Hollinger A, Scheuzger J, Tuchscherer D, Vuilliomenet T, Takala J, Jakob SM, Vang ML, Paelestik KB, Andersen KLD, van der Horst ICC, Dieperink W, Fjolner J, Kjer CKW, Solling C, Solling CG, Karttunen J, Morgan MPG, Sjobo B, Engstrom J, Agerholm-Larsen B, Moller MH, group S-It (2018) Pantoprazole in patients at risk for gastrointestinal bleeding in the ICU. N Engl J Med 379:2199-2208

4. Barbateskovic M, Marker S, Granholm A, Anthon CT, Krag M, Jakobsen JC, Perner A, Wetterslev J, Moller MH (2019) Stress ulcer prophylaxis with proton pump inhibitors or histamin-2 receptor antagonists in adult intensive care patients: a systematic review with meta-analysis and trial sequential analysis. Intensive Care Med 45:143-158

5. Granholm A, Zeng L, Dionne JC, Perner A, Marker S, Krag M, MacLaren R, Ye Z, Moller MH, Alhazzani W, Group G (2019) Predictors of gastrointestinal bleeding in adult ICU patients: a systematic review and meta-analysis. Intensive Care Med 45:1347-1359

6. Butler E, Moller MH, Cook O, Granholm A, Penketh J, Rygard SL, Aneman A, Perner A (2019) The effect of systemic corticosteroids on the incidence of gastrointestinal bleeding in critically ill adults: a systematic review with meta-analysis. Intensive Care Med 45:1540-1549

7. Reignier J, Boisrame-Helms J, Brisard L, Lascarrou JB, Ait Hssain A, Anguel N, Argaud L, Asehnoune K, Asfar P, Bellec F, Botoc V, Bretagnol A, Bui HN, 
Canet E, Da Silva D, Darmon M, Das V, Devaquet J, Djibre M, Ganster F, Garrouste-Orgeas M, Gaudry S, Gontier O, Guerin C, Guidet B, Guitton C, Herbrecht JE, Lacherade JC, Letocart P, Martino F, Maxime V, Mercier E, Mira JP, Nseir S, Piton G, Quenot JP, Richecoeur J, Rigaud JP, Robert R, Rolin N, Schwebel C, Sirodot M, Tinturier F, Thevenin D, Giraudeau B, Le Gouge A, Investigators N-T, Clinical Research in Intensive C, Sepsis g (2018) Enteral versus parenteral early nutrition in ventilated adults with shock: a randomised, controlled, multicentre, open-label, parallel-group study (NUTRIREA-2). Lancet 391:133-143

8. Piton G, Le Gouge A, Brule N, Cypriani B, Lacherade JC, Nseir S, Mira JP, Mercier E, Sirodot M, Rigaud JP, Malaquin S, Soum E, Djibre M, Gaudry S, Thevenin D, Reignier J (2019) Impact of the route of nutrition on gut mucosa in ventilated adults with shock: an ancillary of the NUTRIREA-2 trial. Intensive Care Med 45:948-956

9. Piton G, Le Gouge A, Reignier J (2019) Dose of enteral nutrition and enterocyte biomarker: a circular link? Intensive Care Med 45:1325

10. Arabi YM, Reintam Blaser A, Preiser JC (2019) Less is more in nutrition: critically ill patients are starving but not hungry. Intensive Care Med 45:1629-1631

11. National Heart L, Blood Institute PCTN, Ginde AA, Brower RG, Caterino JM, Finck L, Banner-Goodspeed VM, Grissom CK, Hayden D, Hough CL, Hyzy RC, Khan A, Levitt JE, Park PK, Ringwood N, Rivers EP, SelfWH, Shapiro NI,
Thompson BT, Yealy DM, Talmor D (2019) early high-dose vitamin D3 for critically ill, vitamin D-deficient patients. N Engl J Med 381:2529-2540

12. Casaer MP, Bellomo R (2019) Micronutrient deficiency in critical illness: an invisible foe? Intensive Care Med 45:1136-1139

13. Ostermann M, Macedo E, Oudemans-van Straaten H (2019) How to feed a patient with acute kidney injury. Intensive Care Med 45:1006-1008

14. Heyland DK, van Zanten ARH, Grau-Carmona T, Evans D, Beishuizen A Schouten J, Hoiting O, Bordeje ML, Krell K, Klein DJ, Gonzalez J, Perez A, Brown R, James J, Harris MS, Investigators of the PLPCLT (2019) A multicenter, randomized, double-blind study of ulimorelin and metoclopramide in the treatment of critically ill patients with enteral feeding intolerance: PROMOTE trial. Intensive Care Med 45:647-656

15. Arabi YM, Reintam Blaser A, Preiser JC (2019) When and how to manage enteral feeding intolerance? Intensive Care Med 45:1029-1031

16. Alagna L, Haak BW, Gori A (2019) Fecal microbiota transplantation in the ICU: perspectives on future implementations. Intensive Care Med 45:998-1001

17. Yelin I, Flett KB, Merakou C, Mehrotra P, Stam J, Snesrud E, Hinkle M, Lesho E, McGann P, McAdam AJ, Sandora TJ, Kishony R, Priebe GP (2019) Genomic and epidemiological evidence of bacterial transmission from probiotic capsule to blood in ICU patients. Nat Med 25:1728-1732 